\title{
"Where we stayed was very bad ...": migrant children's perspectives on life in informal rented accommodation in two southern African cities
}

\author{
Nicola Ansell, Lorraine van Blerk 9 \\ Department of Geography and Earth Sciences, Brunel University, Kingston Lane, Uxbridge, \\ Middx UB8 3PH, England; e-mail: nicola.ansell@brunel.ac.uk, lorraine.van.blerk@brunel.ac.uk \\ Received 27 September 2003; in revised form 31 March 2004
}

\begin{abstract}
Most research and initiatives relating to children's experiences of urban space have focused on the physical environment. Housing policies in Third World countries have also emphasised the provision of physical infrastructure and buildings, and urban aesthetics. In this paper the authors draw on the voices of young informants from Maseru (Lesotho), and Blantyre (Malawi), who, in discussions concerning moving house, chose to talk about social and economic aspects of life in the informal sector rented accommodation that is increasingly characteristic of these and many other African cities. The children offer insight into the peopling of urban space, mapping unruly environments characterised by disorder, gossip, and social contestation, far removed from the hard technocratic spaces imagined by planners. Their observations are important not only because children represent a very large and relatively neglected proportion of African urban dwellers but also because they offer a unique insight into the dynamic character of urban environments. As close observers of adult decisionmaking processes, children are informed commentators on motivations for moving house as well as the impacts of urban environments on their own lives. Not only do the children highlight the inadequacies of the informal private rental sector but they also offer a window onto why it is inadequate.
\end{abstract}

\section{Introduction}

The growing attention paid by geographers to the lives and voices of marginalised groups in society led in the early 1990s to a renewed focus on the experiences of children. Geographical knowledge production was critiqued as adultist, and researchers endeavoured to recognise the differing perspectives of young people and their potential as informants. The mushrooming of children's geographies (Aitken, 2001; Holloway and Valentine, 2000; Matthews, 2003) has, however, been largely confined to the experiences of children in the West. In Third World contexts, where children account for as much as half the population, geographical research has focused mainly on children in exceptional circumstances, for example, street children (Beazley, 2000; Young, 2003; Young and Barrett, 2001), and young carers (Robson, 2000; Robson and Ansell, 2000). This is in contrast to research with children in the West, much of which has addressed ordinary children's experiences of everyday spaces, notably the street, playground, school, and home (Holloway and Valentine, 2000). The few studies examining the lives of ordinary Third World children have tended to focus on rural areas (for example, Ansell, 2002; Katz, 1994; Punch, 2000). Given that over a third of Africa's children reside in urban environments (UNDP, 2002), and the importance of place in shaping children's lives (Holloway and Valentine, 2000), there is a clear need for research that explores African children's engagement with urban space.

In the West geographical research has highlighted primarily the significance of the physical fabric of cities to children's lives, stressing the importance of access to suitable space for play and the role of spatial mobility in the development of both environmental awareness and social identity (Matthews et al, 2000a). Although there are significant 
differences between children, relating to age and gender as well as to broader social and cultural distinctions, young people in general use and manipulate urban environments in different ways from adults (Ward, 1990). Geographers have looked both at children's experiences of the built environment and at the social processes that structure their use and experiences of space, with declining access to public space attracting particular concern in recent years (Malone, 2001; Matthews et al, 1999; 2000b). As James et al (1998, page 47) recognise: "The city itself is anything but neutral with regard to social experience and creates a new set of parameters in relation to the child" (emphasis added). Cities are more than physical landscapes, wherein children's use of space is subject to prescriptive moral discourses. The space of the city is also socially, economically, and politically textured.

The work reported in this paper is based on the views of children, mostly aged 12 - 15 years, living in two contrasting southern African cities: Maseru (Lesotho) and Blantyre (Malawi). Specifically, we analyse migrant children's perspectives on life in informal rented accommodation, a situation characteristic of many families in these cities. We begin with an examination of the literature relating to urban childhoods in the Third World, highlighting the neglect of children's perspectives on social and economic aspects of urban life. Second, the growth in the informal rented sector in many African cities is discussed. A case is made for listening to children's views on life in this sector, both because children are affected in unique ways and because they are uniquely positioned as commentators on the social and economic dynamics of the sector. The housing situations of urban Lesotho and Malawi are outlined to provide a geographical context, and the research methods are presented. In the remainder of the paper we draw on the children's voices, revealing their impressions of, in particular, the social and economic aspects of life in the informal rental sector. The children's comments not only demonstrate that they are aware of the impacts of renting on their own lives but permit insight into why it is that there is a connection between renting and migration.

\section{Children's experiences of urban life in the Third World}

The lives of ordinary children in Third World cities, although relatively neglected by geographers, have attracted greater interest from other disciplines. A number of publications in the mid-1990s to late-1990s argued for greater consideration to be given to children's experiences of urban environments, focusing in particular on the impacts of environmental conditions for children's health (for example, Bartlett et al, 1999; Satterthwaite et al, 1996). This movement towards a recognition of children's particular needs in urban development and planning was reflected in the acknowledgement of children's rights by the United Nations Conference on Human Settlements (Habitat II) in Istanbul in 1996, with the launch of Children's Rights and Habitat (UNHCS/Habitat, 1996) and the UNICEF Child-friendly Cities initiative.

\section{Children's environmental needs}

The literature described above addressed wide-ranging impacts of city life on children. Those most relevant here are discussions of children's experiences of homes and residential neighbourhoods. Satterthwaite et al (1996) suggest that four aspects of a household's environmental context are important for children: the indoor environment; the immediate outdoor environment; infrastructure and service provision in the residential area; and controls over air, water, food, soil, and noise pollution. It is widely recognised that young children generally spend a large part of their time in the dwelling and in shared courtyards or other areas immediately outside it (Bartlett et al, 1999). It is important for children's social identities that they have adequate access to space within and outside the home and also that such areas are as free as possible from 
environmental hazards (Bartlett et al, 1999). Neighbourhood spaces are seen to pose environmental hazards to children playing (Malone, 2001), and conditions that are adequate for adults may be harmful for children (Bartlett et al, 1999).

Although much of this literature on children in Third World cities, including Children's Rights and Habitat (UNHCS/Habitat, 1996), has emphasised access to physical space and the physical hazards associated with urban life, it is acknowledged that the physical environment alone is not responsible for children's experiences of urban life. Rather, these are also shaped by children's social and economic contexts (Satterthwaite et al, 1996; Tranter and Pawson, 2001; UNHCS/Habitat, 1996). While adequate, secure, housing may be an important component of the stable and secure family context that is regarded as crucial for children, this should be recognised to mean more than simply shelter (Bartlett et al, 1999).

Children's Rights and Habitat advises that "Families must have legal security of tenure and must be protected from the traumatic effects of forced eviction and displacement" (UNHCS/Habitat, 1996, page 5). Secure tenure is highlighted frequently in the literature, but is discussed primarily in relation to its significance for improvement and investments in property and its importance as an economic asset, giving access to credit and security against economic vulnerability (Satterthwaite et al, 1996). The negative social impacts on families of insecure tenure are less widely recognised. These cause anxiety and stress and may make it difficult for children to establish a sense of belonging in a place (Bartlett et al, 1999). It is also suggested that parental anxiety can have indirect negative impacts on children's lives (Bartlett et al, 1999). Forced eviction is seen as particularly problematic, causing a range of impacts, including homelessness, economic upheaval, destruction of property, family separation, interruption of education, financial difficulties, and children having to enter the labour market (Bartlett et al, 1999).

All of this literature is derived primarily from adult assessments of children's needs: recommendations concerning housing tenure (for example, Bartlett et al, 1999) are based upon the presumed benefits to children of particular arrangements rather than on consultations with children. There is, however, a second strand of literature on Third World children's lives, emerging from a tradition that seeks to speak with rather than for children (Hart, 1992; Stephens, 1994) and takes as its starting point the notion that "children are the best experts on local environmental conditions as they relate to their own lives" (Chawla, 2002a, page 14).

\section{Children as commentators on urban life}

In the 1970s Kevin Lynch, an urban planner, developed a UNESCO-funded project that became known as Growing Up in Cities (GUIC). This examined children's experiences of urban environments in four countries across the globe (Argentina, Australia, Poland, and Mexico), giving voice to 10 - 15 year olds in relatively low-income neighbourhoods of large cities (Lynch, 1977). A variety of methods were employed, including observations of children, interviews with children focused around their maps and drawings of their environments, and guided tours with children, as well as the collection of secondary data and interviews with parents and local officials (Lynch, 1977). The outcome was a series of rich narratives reflecting a detailed understanding of children's use of, and attitudes towards, their residential environments. However, although one of the project's intentions was to "help document the human costs and benefits of economic development" (Lynch, 1977, page 1), particularly where studies were led by architects, planners, and psychologists, the focus was more on understanding how everyday places functioned for children rather than on economic analysis (Chawla, 2001). This is perhaps compounded by the predominantly visual methods that were used in a way that drew more attention to the physical urban fabric than to less tangible conditions of existence. 
In the 1990s GUIC was revived, employing similar strategies designed to "collect information about young people's contemporary urban experience" (Chawla, 2002b, page 29). At this time children-centred research was enjoying a new popularity and respectability (see, for example, Boyden and Ennew, 1997), and the study was extended to a number of new localities, including Johannesburg in South Africa. Children in the recent studies identified a range of indicators of environmental quality that included both physical and social qualities (Chawla, 2001): "Along with having material needs, children also need the 'shelter' of a cohesive and friendly local culture" (Chawla, 2002c, page 33). Children's experiences of life in rented accommodation are not specifically discussed, although security of tenure is highlighted in relation to children's experiences in Canaansland squatter camp in Johannesburg. Swart-Kruger (2002) describes the forced eviction of the Canaansland residents and their relocation to a distant site where they came into conflict with existing settlers. This experience encouraged Chawla (2002d) to draw attention to secure tenure and social integration as key contributors to children feeling positive and comfortable about where they live. This evokes earlier research by Reynolds (1989), who discussed a range of ways in which the general context of poverty, insecurity, and political violence impinged on children in the Crossroads squatter settlement on South Africa's Cape Flats. Similarly, Jones (1993) gave South African children space to describe their experiences of migration and their perception of life in the migrant workers' hostel they inhabited. In these studies, however, it is the author who extrapolates the influence of wider social and economic contexts upon the children concerned. Equally, although Swart-Kruger demonstrates children's awareness of the sociopolitical context in which they live (see also Swart-Kruger and Chawla, 2002), in her account of the Canaansland removal, children do not relate their own experiences of eviction, which happened after the data-collection stage of the GUIC project (Swart-Kruger, 2002).

Despite assertions that children are experts on their own lives, they have seldom been given the opportunity, in research, to comment on the social and economic processes that structure their existence in rented accommodation in cities in the Third World. The research reported here demonstrates that they are able to offer informed opinions. Children in both Maseru (Lesotho) and Blantyre (Malawi) introduced the issue of housing tenure and indicated a range of ways in which their tenure situation influences their experience of city life, particularly in relation to moving house. Significantly, their comments not only reveal first-hand accounts of the impacts of renting on children but also offer a window onto the dynamic character of urban social environments. As close observers of family decisionmaking processes, children show that they are qualified to comment on adult motivations for moving house as well as on the impacts this has on their own lives. Thus the children not only highlight the inadequacies of the informal private rental sector but also offer a lens onto why it is inadequate.

\section{Informal sector rented housing in African cities}

It has been estimated that the majority of residents of African cities inhabit rented accommodation, yet the rental sector has, until recently, been largely neglected in research (Grant, 1996). This in part reflects a lack of attention to the sector in urban development policies (Andreasen, 1996), with the facilitation of growth in rented accommodation having been widely perceived as undesirable (Watson and McCarthy, 1998). Housing policy in post-Apartheid South Africa has, for instance, been geared to achieving self-contained owner-occupied housing for all (Huchzermeyer, 2001; Morange, 2002; Oldfield, 2000). Provision of housing for ownership has seldom, however, been able to meet housing demand, particularly among the very poor, and 
universal owner-occupation is increasingly considered an unrealistic aspiration, even in countries as affluent as South Africa (Huchzermeyer, 2001; Morange, 2002).

The steady growth of the rental sector is not entirely attributable to shortage of housing for ownership but relates also to a range of other factors, some of them locally specific, others more widespread. Research in South Africa has shown that renting can offer cost advantages over owner-occupancy, along with better locations (Watson and McCarthy, 1998). Backyard shacks, in particular, are seen as a cheap, safe, and secure housing option offering flexibility and access to services, without the dangers associated with South African squatter camps (Morange, 2002). Furthermore, in many parts of Africa rural-urban migration is seen as a temporary undertaking: research in both East Africa and Malawi suggests migrants usually expect to return to their rural homes and therefore prefer to rent when staying in town (Andreasen, 1996; Englund, 2002).

Whereas the demand for rented accommodation has grown, however, government and formal commercial provision of low-income rental housing has fallen in most African countries (Watson and McCarthy, 1998). This is an outcome of neoliberal agendas being brought to bear on public policy. Structural adjustment in the 1980s and 1990s led to a widespread decline in public sector rented housing. In Zimbabwe, for instance, local authorities were prevented from building new properties and were encouraged to sell housing stock to tenants or, more often, to more wealthy individuals (Grant, 1996). On the supply side, research in East Africa shows that in times of economic instability those with sufficient income may see investment in housing as a safe option (Andreasen, 1996; Briggs and Mwamfupe, 2000).

In the absence of government and formal commercial provision, rented housing is increasingly provided by small private landlords and occupied by the poor. Although wide variations in the nature and security of tenure exist within and between African cities (Andreasen, 1996), across much of Africa, Asia, and Latin America "Most of these landlords reside on the same property as the tenants and few landlords have more than a couple of properties" (Watson and McCarthy 1998, page 53). Such forms of provision meet with enthusiasm from international institutions such as the World Bank, keen for private sector solutions to Third World urban housing shortages (Sandhu and Aldrich, 1998), and there are growing calls for policy to support the private informal sector in providing rental units for low-income households (Crankshaw et al, 2000; Ogu and Ogbuozobe, 2001; Sandhu and Aldrich, 1998).

This new enthusiasm for the informal rental sector has not met with universal approval. Wilkinson (1998), for instance, suggests that very poor South Africans may be unable to access adequate accommodation through housing markets. The severe shortage of housing for rent under conditions of rapid urban growth in Zimbabwe has led to cases of exploitation by landlords and landladies (Grant, 1996). Elsewhere the private rental sector has been associated with problems such as poor quality accommodation and overcrowding (Watson and McCarthy, 1998), and poor maintenance and lack of access to infrastructure (Andreasen, 1996). The reduction in rent control programmes under structural adjustment have also made it difficult for some families to access adequate housing (Bartlett et al, 1999). Significantly, the focus of both policy and critiques has been on the provision of structures and infrastructure and on who is able to access these, rather than on nonmaterial attributes of informal housing space, including the extent to which housing solutions are 'liveable', and the role of social capital (Oldfield, 2000).

The impacts on people of life in informal sector rented housing remain underresearched. Significantly, women and children often constitute the majority of tenants but have received the least attention (Muzvidziwa, 2003). Children have particular interests in relation to the urban environment, and their distinctive positioning in 
society allows, or requires, them to map urban informal rented space in different ways from adults. It is worthwhile listening to children's voices, not only for what they tell us about how rented housing impacts on children's own lives but also because they offer an alternative insight into the dynamics of life in the informal sector. Children offer perceptive accounts of numerous 'everyday' issues that are frequently omitted from the descriptions of urban life captured through research with adults. Children's awareness of the microsocial dynamics of urban environments can contribute, in particular, to our understanding of why urban informal rental households migrate, and the resultant fluidity of informal neighbourhoods.

\section{Case studies}

Although the informal rental sector is expanding across Africa, local and national patterns of housing provision and tenure are immensely varied, reflecting the historical and contemporary roles of central and local government in providing and regulating housing, the enforcement of regulations, the role of employers and of social and cultural traditions, as well as rates of urbanisation and characteristics of rural-urban migrants. The research reported here relates to two cities that have contrasting histories and contemporary experiences of housing: Maseru (Lesotho) and Blantyre (Malawi).

\section{Maseru, Lesotho}

Prior to independence in 1966 Maseru, Lesotho's capital city, had only about 15000 inhabitants (Gay et al, 1995). By 2002 the population had risen to as many as 350000 (SC/GPA, 2002). The average annual growth rate from 1990 to 2001 was 5.1\%, exceeding the Sub-Saharan average of $4.7 \%$ (UNICEF, 2003), and growth is now estimated at $7 \%$ a year (SC/GPA, 2002).

Housing was not a great priority in Lesotho after independence (Gill, 1994). Some public rented housing was built in Maseru, but today there are just 180 units, catering only for higher-income households (SC/GPA, 2002). In the late 1970s and early 1980s efforts to control Maseru's growth led to government housing schemes at Mohalalitoe, Khubetsoana, and Mabote (Ambrose, 1993). Subsequent efforts at planning housing development in peri-urban Maseru have had little success (Gay et al, 1995). The 1987 National Housing Plan, which envisaged provision of serviced plots to be developed by owner-builders (Gay et al, 1995), was never adopted by the government (Gill, 1994). Commercial housing provision falls far short of demand (SC/GPA, 2002).

Instead, the growth of Maseru has continued largely unplanned (SC/GPA, 2002). Beyond the $3 \mathrm{~km}$ radius from the $\mathrm{CBD}$ that fell within the jurisdiction of district council planning controls, growth progressed as incomers (and urban speculators) acquired fields from local chiefs (Ambrose, 1993). Despite efforts to restrict the practice, illegal payments to chiefs have often secured claims to freehold and by 1980 peri-urban Maseru already accommodated $80 \%$ of the city's population (Ambrose, 1993). Because the expansion of Maseru has been permitted to proceed relatively unrestricted, the density of building is generally low and plot sizes large (SC/GPA, 2002). There are few of the overcrowded squatter settlements that characterise many African cities.

Most houses in Maseru are constructed by their owners. However, not all homes are owner-occupied. A survey of urban Lesotho found $23.7 \%$ of households to be renting, but this is believed to underestimate the true figure (Gay and Hall, 2000). Most tenants inhabit houses built for rental, usually on the compounds of residents with money to invest. These are generally malaene, or 'lines': long rectangular buildings of concrete blocks or sometimes baked brick, with corrugated iron roofs, divided into one-room units, each with a door and window onto a communal yard. 
Tenants may rent and occupy one or more units. The lines are of varying quality, but most are robust structures and some have electricity and a few an internal water supply. Landlords and landladies may own several lines, either on the same compound or more dispersed across the city (SC/GPA, 2002).

Most tenants aspire to own a home but are constrained by cost, yet renting in Maseru is not an indicator of poverty. In contrast to South Africa (Crankshaw et al, 2000), rents are relatively high, and households that rent their homes fall into all economic categories, with renting more common where there is a wage worker in the household (Gay and Hall, 2000). Indeed, it is not uncommon for a person to be both tenant and landlord (SC/GPA, 2002). When an individual acquires a plot of land, he or she may build a line to obtain rental income prior to constructing his or her own home. Equally, where an owneroccupier obtains employment elsewhere, he or she is likely to find tenants for his or her house and rent a home close to the new place of work (Muzvidziwa, 2003).

Not only are Maseru's rented homes and their tenants very varied, most neighbourhoods comprise a mixture of housing types, as immigrants to the city progressively improve and develop their homes as their income permits. There are exceptions: Thibella, close to the city centre, accommodates very poor newcomers to the city, along with 'failed' migrants who have been unable to find work. Here most homes are poorly constructed shacks. Across most of peri-urban Maseru, however, "Substantial houses of considerable luxury are mingled with malaene and small cement block houses" (Ambrose, 1993, page 194).

\section{Blantyre, Malawi}

Blantyre's population increased by 44\% between 1987 and 1998, reaching 502 053, and retaining its place as Malawi's largest city, with $36 \%$ of the urban population (NSO, 2000). By the time of the 1996 census, approximately half of Malawi's urban population lived in rented accommodation, and half inhabited their own homes (NSO, 2000). It often takes rural-urban migrants several years before they are able to buy or build a house, and most expect ultimately to return to their village of origin, which makes renting a sensible option (Englund, 2002).

Living standards are generally lower in Malawi than in Lesotho, with respective per capita GDPs of US \$615 and US \$2031 and Human Development Index rankings of 163 and 132 (UNDP, 2002). Of the 802650 residents of Blantyre District, 217165 inhabit dwellings classed as 'permanent', 348249 'semipermanent', and 237236 'traditional'. More than two thirds reside in homes with one to three rooms. Just over half have access to piped water, either inside or (in most cases) outside the dwelling, and most rely on firewood for cooking and paraffin for lighting (NSO, 2000). Rents are relatively high: a two-bedroom house costs about MK 1000 a month, which compares with a minimum wage of MK 55 a day (Kishindo, 2003).

Malawi's low-income urban housing areas, which accommodate most city dwellers, are officially designated either as 'traditional housing areas' (THAs) or as 'squatter settlements' (Englund, 2002). By 1993 82\% of Blantyre's population inhabited THAs, where housing was officially the responsibility of the Malawi Housing Corporation (MHC). When new housing was to be built, the MHC demarcated plots, on each of which it provided a pit latrine. Roads and piped water were to be built within 1000 feet of each plot. Plots were allocated to individuals on leases of 33, 66, or 99 years, and occupants were expected to construct a home within six months. Although seemingly more strictly regulated than housing in Lesotho, in practice most plots are multiply occupied with an average of five and as many as ten dwellings each. Most residents are monthly tenants of the plot holders. Although it remains illegal to sell a plot, some plot holders have profited from selling their plots to prospective landlords (Englund, 2002). 
'Squatter settlements' are technically illegal but, since the political reforms of 1994 , which encouraged a sense of freedom and security, their populations have increased (Englund, 2002). Living in a squatter settlement is often more attractive than in a THA because rents are lower, stringent building conditions do not apply, and there was (at first, at least) more space. Increasingly, these areas are serviced with water points, schools, and electricity (Englund, 2002). As in the THAs, however, houses are small.

\section{The research}

In this paper we draw on data derived from a wider research project exploring young people's experiences of migration in light of the AIDS epidemic. Research was undertaken with children in Maseru and Blantyre, as well as with rural communities in Lesotho and Malawi. The rural communities, to which occasional reference is made below, were Ha Tlali, in the foothills of Lesotho's Maluti Mountains, and Mpando village, in the tea-growing Thyolo District, Malawi.

The urban children participating in the research were from Standards 6 and 7 of St James' Primary School and Form A of St James' High School in Maseru, and from Standards 6, 7, and 8 of Ndirande Primary School in Blantyre (children remain at primary school a year longer in Malawi). Classes are not of uniform age but, although a wide range of ages was represented (the youngest was 10 years old, the eldest 20 years old), over $75 \%$ of participating children at each school were aged between 12 and 15 years. All are large government schools (Ndirande Primary has over 9000 pupils) and draw their students from homes of low to middle income. Wealthier households tend to educate their children in private schools, and a minority of very poor urban children drop out of primary school before reaching the upper primary classes. Ndirande Primary School serves the large township of Ndirande, which emerged as a squatter settlement in the 1950s, outside the boundary (and therefore planning controls) of Blantyre. Even in the early 1970s, a period of very rapid growth, most of the houses in the poorer part of Ndirande were rented (Norwood, 1972). Today the typical Ndirande household resides in a 1-3 room house built of mud brick. St James' Primary and High Schools, by contrast, are centrally located on the eastern edge of Maseru city centre and serve a wider geographical catchment, including the suburbs of Lithabaneng, Khubetsoana, and Qoaling. The family circumstances of children attending the schools are varied. Some households in both cities have a steady income from employment, others do not. Some children live with both parents, some with one parent, many with other relatives. Many of the children have been affected indirectly by the impact of the AIDS pandemic that struck Malawi in the early 1990s and Lesotho in the late 1990s.

A range of methods were employed. A questionnaire (in both English and the local language) was distributed to about 200 children attending schools in each community in order to identify children who had moved house. Focus group discussions (FGDs) were held with about fifty migrant children in each community. Separate focus groups of girls and boys were drawn from each year group. Additional FGDs were conducted with out-of-school children in Ndirande, and in Lithabaneng, a very large and mixed suburb of Maseru, as well as with children living in residential care and with street children in both cities. The FGDs were conducted in the local language with the aid of an interpreter and began with general questions about migration-who moves, why people move, and who makes decisions about migration. Children were also asked to compare life in their current and previous homes. A subset of these children, whose migration was believed to be AIDS related, were invited to draw storyboards. These children drew a sequence of six pictures relating their migration experiences and were then invited to talk (through an interpreter) about their drawings. 
Emerging very clearly from the pictures and discussions among urban children in both countries was a strong association between migration and living in rented accommodation. Children spoke both from personal experience and in more general terms about what happened in their communities, drawing on broader cultural discourses around renting. Their descriptions of life in rented housing, and in particular the problems that prompted people to move from their homes, were vivid and offer a window onto their experiences and feelings about life in their respective communities.

The fact that the subject of rented accommodation was tangential to the original focus of the research has some interesting consequences. Because children's descriptions of life in rented housing arose in discussions of migration, the research could not easily capture the views of those who do not associate renting with migration. Although the FGDs provided children with the opportunity to contest viewpoints they disagreed with, those who had not moved house, and may have found renting an unproblematic experience, were not included in the discussions. Hence the findings reported here represent a somewhat incomplete picture of children's experiences of life in rented accommodation. Very significantly, however, it seems likely that, had the research set out to explore children's views on where they lived, the research design would have more likely elicited children's thoughts on the material environments of their lives and missed the social and economic aspects that are clearly important to them.

The bulk of this paper is based upon an analysis of references made by children to life in rented accommodation in transcripts of the FGDs and (to a lesser extent) storyboard interviews. Although it is important to acknowledge the differences among the young participants in terms of age, gender, and background, individuals are not identified in the FGD transcripts: data emerging from FGDs should be seen as the product of the group rather than of individual participants (Stewart and Shamdasani, 1990). Quotations employed in this paper are therefore related to the characteristics of the group (the school or community, class, gender, whether the child was attending school), not to individual children. Given the relatively undirected nature of the discussions, some groups chose to discuss certain themes that did not arise among other groups. Although the groups were stratified by year of school, no group was of homogeneous age, and the average age difference between Standard 6 and Standard 8 or Form A is only two years. Unsurprisingly, no systematic differences emerged relating to year of schooling. Differences relating to other characteristics of the children were seldom very clear-cut, although there were some issues, as will be outlined below, that dominated discussion in the girls' groups more than the boys' groups or among the out-of-school children more than those attending school. Caution is necessary, however, in generalising from the characteristics of groups, particularly given that only eleven FGDs were held in Maseru and eight in Blantyre.

\section{Life in rented accommodation}

There is a strong association in many children's minds between migration and living in rented housing. In response to the question 'Who migrates?', similar statements recurred frequently among the various answers given in FGDs in both cities:

"People that live in the lines" (Standard 7 boys' FGD, Maseru);

"Those that live in other people's houses" (Standard 6 boys' FGD, Maseru);

"those who rent houses" (children's home FGD, Malawi);

“Tenants" (Standard 8 girls' FGD, Blantyre). 
The insecurity and disruption caused to children by migration is detailed elsewhere (van Blerk and Ansell, under review). On the whole, moving home was not popular among young people. Many described how property was damaged or stolen in the process of moving, and they were concerned by the costs of hiring transport. More significantly, it removed them from their friends and disrupted their education. Enforced migration, which is not uncommon among tenants, as will be explored later, is particularly problematic. This has been shown to reduce young people's control (both actual and perceived) over their own lives (Magwaza, 1992).

\section{The accommodation}

When children elaborated why they associated moving house with people in rented accommodation, their answers revealed much about their perceptions of life in the rental sector. A few of the children referred to the condition of the houses they occupied:

"I was happy to leave [the rented house] because the house was leaking and stuff got spoilt" (Agnes's storyboard, aged 15, Maseru).

A girl in Blantyre talked of moving from rented accommodation because of a "shortage of toilets". Comments relating specifically to the quality and maintenance of rented houses, however, were few. Although a number of children referred to having moved because their house collapsed or caught fire, this was more common among rural children, and it was never explicitly related to the tenure of the house. Some had moved into houses that had electricity, but this might happen within the rental sector or outside it. Similarly, some children described having moved because their home was too small and crowded, but this was also true of children in rural areas and was more a function of family size than a characteristic of rented housing. Thus urban children resident in rented accommodation were more concerned about other aspects of life in the rental sector than the physical conditions of housing which have received attention in the literature.

\section{The neighbourhood}

More commonly, children in rented accommodation referred to the characteristics of the neighbourhood. Problems with neighbourhoods were discussed by most focus groups, but particularly dominated discussion by the Maseru out-of-school boys, among the most impoverished and unsettled of the Maseru respondents. Only a small minority of children talked of the physical environment of their home areas. There were some who mentioned dirt and untidiness, but even these related the physical state of the neighbourhood to social conditions such as gossip and quarrels. Indeed, no real distinction was made by children between the social and material aspects of their neighbourhood, these being perceived as closely interrelated. Neighbourhoods were represented as auditory as much as visual spaces, and products of social contestation:

"The difference [here compared with the previous place] is there is no gossiping, quarrels and untidiness, so it is a better place to stay, but where we stayed was very bad, that place, even if you just saw the place you would realise that there was really a need to migrate" (Standard 6 girls' FGD, Blantyre).

"The difference is that at the first place they gossiped and were noisy and also untidy, but we are now staying peacefully at the new place" (Standard 6 boys' FGD, Blantyre).

It was the social contestedness of their neighbourhoods that dominated children's descriptions of reasons for moving. Areas of mainly rented housing were, for instance, perceived to have high levels of crime. Concerns ranged from theft of material property to risk to lives: 
"A family can move house if they see many things happening in their area, maybe robbers are giving them problems and some are getting killed" (Standard 8 boys' FGD, Blantyre).

Often, though, it was more general conflicts with neighbours that pushed families away. Good relationships with neighbours have been identified as important for children's well-being in cities (Bartlett et al, 1999; Chawla, 2002c), but children depicted their neighbourhoods as characterised by fighting, often fuelled by alcohol:

"People who live at the lines are always fighting and swearing" (out-of-school girls' FGD, Maseru).

"When I was at Moshoeshoe II there were times when there was a lot of trouble and conflicts just like here in Lithabaneng. All these troubles are caused by alcohol-people end up fighting" (out-of-school boys' FGD, Maseru).

Another commonly reported attribute of neighbourhood life was gossip. Children noted that household decisions to move were often prompted by their mothers, who resented being talked about by neighbours:

"When a family moves, it's usually because they don't live well with the other people in the neighbourhood" (Standard 8 boys' FGD, Blantyre).

"Sometimes the mother is the one who mentions the lies of other women in the neighbourhood" (Standard 8 girls' FGD, Blantyre).

"There are some people who like to gossip about other people and because of this they end up hurting other people. They start to fight and insult one another and because of the fighting and swearing one can decide to move to another place" (Standard 7 girls' FGD, Maseru).

Although gossip is not necessarily a direct product of living in rented accommodation, where renting predominates across large areas, as in Ndirande, communities are less settled and stable and people know each other less well. Arguably, tenants who see themselves as temporary residents invest less in their neighbourhoods - not only in the physical fabric as suggested by Bartlett et al (1999) but also in the generation of social capital. Although most Maseru neighbourhoods are of mixed tenure, tenants of the lines share amenities such as toilets with their immediate neighbours, who are also renting, which can cause difficulties (Muzvidziwa, 2003). The Maseru children talked in detail about the particular issues that underlay conflicts with neighbours: arguments over dumping of rubbish, the return of borrowed items, trespass, and use of water supplies. These are not major issues, but are clearly contentious where people live in close proximity, have few resources, and lack the strong community relationships that might facilitate conflict resolution. Although the issues may not impinge directly on children, the disagreements they provoke give rise to a general aura of conflict within the neighbourhood:

"Sometimes you don't leave the place on good terms with other people-some of the villagers ${ }^{(1)}$ don't talk to you, because you'd have fought over where one should dump their rubbish - some say you empty your rubbish in their yard, then people get upset because of all this" (Standard 7 girls' FGD, Maseru).

"Sometimes people lend each other things. Then another person doesn't return what [he or she] has borrowed, then people fight - there's no peace and then one can move" (out-of-school boys' FGD, Maseru).

(1) The term 'village' was commonly applied by children in both cities to areas of the city that fell under a single chieftainship. 
"When we lived there I used to spend the whole day looking out for people who were coming to draw water without the owner of the compound's permission" (Standard 6 girls’ FGD, Maseru).

Tenants have little recourse to external conflict resolution. Property owners may or may not choose to become involved in conflicts concerning their tenants, but on the whole they lack authority. Most urban areas in theory come under the authority of a local chief, who might expel particularly troublesome villagers. Many urban communities, however, are so large, rapidly growing, and fluid that chiefs cannot know all the people and are certainly unable to intervene in disputes. Rather than settle conflicts, children suggest that most tenants simply leave or are evicted. Although this may offer an immediate (if temporary) solution for the individual, it also contributes to the more general problems that result from the absence of a settled community:

"I moved from Khubetsoana because my father always used to argue with the other villagers, and they used to come to our house and fight our dad. The owner of the site didn't do anything - [the owner] just looked at them" (Standard 7 girls' FGD, Maseru).

"Some move when the chief tells them to, due to their behaviour" (Standard 6 girls' FGD, Blantyre).

Although almost all of the disputes children described were between adults, conflict, even at a relatively low level, impinges on children's lives. Swart-Kruger (2002) describes the disputes between ethnic groups in a Johannesburg squatter camp that, although involving adults, affected children's experiences of urban life. Living in a general atmosphere of conflict can cause children stress and have adverse consequences for their mental health (Fraser, 1973). Some children were also affected by neighbourhood disputes in more concrete ways:

"Sometimes our parents don't like us playing with other children because they don't like or get along with the parents of these children" (out-of-school boys' FGD, Maseru).

Children also offered solutions to the problems they perceived:

"There should be a curfew set in the whole village and anyone found out of their home after the time set should be lashed or jailed" (Standard 7 girls' FGD, Maseru).

This may appear a harsh judgment but reflects the strength of feeling of children on neighbourhood security as well as the fact that children themselves are often effectively subject to curfews in urban environments, which are enforced by their guardians, often by threat of physical punishment.

\section{The landlord or landlady}

Of comparable significance to their relationship with their neighbours, in children's accounts, was the household's relationship with its landlord or landlady. Crankshaw et al (2000) have pointed to largely nonexploitative relationships between the landlords and tenants of the backyard shacks of Soweto, South Africa, but in both Lesotho and Malawi the construction of accommodation for rent is intended to be lucrative (Englund, 2002; Muzvidziwa, 2003). Englund (2002, page 149) comments in relation to Malawi: "the provision of housing is a profitable business, increasingly conducted by landlords and landladies who rarely have the welfare of tenants close to their hearts." Children in many of the FGDs in both Maseru and Blantyre described difficult and conflict-ridden relationships with landlords and landladies that prompted migration. The Maseru out-of-school boys were particularly vocal in this respect. 
"[people migrate] because they are not living peacefully - they are always in conflict with the owner of the lines" (out-of-school boys' FGD, Maseru).

"Migration is moving from a place you live at and going to live in another house, because the owner of the previous house is troublesome, so one feels it's better to move to another house and hopefully the owner there won't be troublesome" (Standard 7 boys' FGD, Maseru).

Many landlords and ladies were accused by children of being badly behaved, frequently drunk, gossiping about their tenants or even practising witchcraft [a phenomenon often blamed for cases of HIV/AIDS (Munthali and Ali, 2000)].

"[People move] because the landlord is badly behaved" (Standard 8 girls' FGD, Blantyre).

"The bad things I meet are that when the landlord is drunk he always gossips" (Standard 7 girls' FGD, Blantyre).

"The owner of the lines talks about you behind your back, telling people you are poor and struggle a lot” (out-of-school boys' FGD, Maseru).

"I felt happy [to leave] because our landlady was a witch, so I was happy moving away from such a place" (Standard 6 boys' FGD, Blantyre).

In conditions of high demand for housing, there is little incentive for a landlord or landlady to invest in relationships with his or her tenants. There is no enforced legal requirement to offer secure tenure, and problematic tenants can easily be replaced.

Children may constitute the majority of the residents of rented urban housing (Muzvidziwa, 2003), and sometimes their own behaviour causes difficulty in the relationship between tenant and landlord or landlady. Children described how their actions sometimes cause disputes, which might ultimately lead to their family's eviction from the house. Children are thus vested with considerable responsibility for the situations of their households:

"Children can cause trouble between their parents and the owner of the lines. Children fight and insult the other child's mother" (out-of-school boys' FGD, Maseru).

"Sometimes one has children and they always play with the doors and this doesn't make the owner of the compound happy" (Standard 7 boys' FGD, Maseru).

"My mother moved because the owner of the lines didn't like many children. Our friends used to visit us and she used to say we were making a lot of mess in her [garden or yard]" (out-of-school boys' FGD, Maseru).

Children's concerns, however, lay not only with social aspects of life in rented accommodation. They were also acutely aware of the implications of having to pay rent. This was also a view held by rural children, some of whom had previously lived in town:

"In Maseru these people aren't able to get a lot of things because at the end of the month they have to pay rent" (10 - 13 year old boys' FGD, Tlali).

"I think it's painful, just because you live in a rented place, at the end of the month you have to pay rent and you find that your parents don't have money" (Form A girls' FGD, Tlali).

Many children found the regular uncertainty over their guardians' capacity to pay the rent highly stressful. A number, particularly among the out-of-school boys in Maseru, had experienced eviction, sometimes at short notice, and felt their landlords or landladies had lacked sympathy for the difficulties their families faced. Both of the children quoted below had suffered the loss of a parent, as have many in the current AIDS crisis: 
"Now there are problems as my brother-in-law was working for a building society, but he lost his job 9 months ago and is just staying at home and the landlord is still increasing the money for the house and we can't pay as he's not working" (Nora's storyboard, aged 13, Blantyre).

"My father had just died, and as soon as he was buried we were sent away from the lines because we didn't have money to pay rent" (out-of-school boys' FGD, Maseru).

Some children in similar situations experienced repeated evictions, as their parents or guardians repeatedly failed to earn enough money to cover the rent. It is not, however, always inability to pay rent that leads a landlord or landlady to evict a tenant. Conflicts arising over other issues may prove sufficient provocation, and eviction could happen suddenly and in difficult circumstances:

"Moving house is when you were living at the lines and the owner of the lines no longer likes you, so you move to live at different lines" (Standard 6 girls' FGD, Maseru).

"We used to live in Maseru. We lived in somebody's house, then my father broke the window, then we moved. My father was sent away, and my mother went to find work in Gauteng [the Johannesburg area], then we came here" (out-of-school girls' FGD, Tlali).

"[Migration] is bad because you leave unexpectedly - the owner of the house could be evicting you and you might have to move at night" (Standard 7 boys' FGD, Maseru).

The children's comments quoted above both reflect and feed broader societal discourses in which renting carries negative associations. Renting is seen by some children, however, not only as unfavourable but even as a cause for shame. Some Maseru children (most of whom live in neighbourhoods of mixed tenure) reported being teased or insulted because they lived in rented houses:

"The children in our new place are silly and have no respect. They say we live in a rented house" (Standard 7 girls' FGD, Maseru).

\section{Homeownership}

Many children, particularly in two of the girls' FGDs in Maseru (in which owneroccupancy is more familiar), expressed an aspiration to live in their own home. This was not an aspiration to inhabit a bigger or better home, but was related more to questions of cost and security. For most, the primary advantage was not having to pay rent, several children having moved for this reason:

"We moved because the monthly rent was becoming expensive, so my parents bought block bricks to build a house" (Standard 7 girls' FGD, Maseru).

"[Life] has changed because life at home is pleasant when our parents get their salaries at the end of the month, they are able to get the stuff we need, the money doesn't all go to pay for the rent" (Standard 7 girls' FGD, Maseru).

"Moving is fun because you'd be moving from a rented house to your own home, where you can be free and do whatever you want. You even stop wondering when your mother will pay rent when there is no money" (Standard 7 girls' FGD, Maseru).

Apart from the removal of anxieties concerning whether rent would be paid, children mentioned other advantages relating to stability of lifestyle: there would be no risk of eviction, and for some children the appeal was that they would never again have to move house: 
"It's nice because if the owner of the rented place comes to throw you out of the house, you just leave and move into your own house and no one troubles you" (out-of-school girls' FGD, Maseru).

"Just find a big place and build your own house so that you never migrate again" (Standard 8 boys' FGD, Mpando).

Some children could see other advantages that stability and security would bring, in relation to the physical environment in which they lived, and socially. Having escaped the chaotic, unruly spaces of the rental sector, it was considered possible to settle into a quieter environment where there would be time to give attention to one's physical and aesthetic surroundings:

"We no longer live in a rented place. We get along and converse with the people we now live with, and our parents talk" (out-of-school girls' FGD, Maseru).

"I think that the good things are that, when you live in a house that is not yours, you don't take good care of the house, but in your own house, you take extra good care of the place, you even plant flowers" (Standard 7 girls' FGD, Maseru).

\section{Conclusions}

Problems of living in rented accommodation emerged repeatedly as a theme in research that asked in general terms about where children lived and reasons for moving home. Many children who had moved had done so for reasons associated with living in rented housing. Although renting was only one of several reasons for migrating discussed by children in this research it was clearly an issue of concern to many: a concern related both to local discourses about renting and to children's immediate experiences.

Children's reflections on life in the rental sector in both cities related less to the nature of their homes, or even to the physical fabric of the wider neighbourhood, than to the social and economic consequences of the prevalent tenure system. It was these intangible aspects of renting that children saw as prompting migration. Furthermore, children themselves made connections between their urban experiences and neighbourhood-level social, economic, and political processes.

Research with children concerning their experience of place has tended to focus on the physical environment, and children's understanding and perceptions of it, to the relative neglect of the social and economic characteristics of different places, as they are seen by young people. Where children's input into urban planning has been encouraged, this has been seen largely in terms of suggested changes to the physical environment. Prompted, albeit indirectly, to talk about negative aspects of their home environments, children talked primarily about the relationships between their families and their neighbours and the owners of their homes, and about the drawbacks of having to-and sometimes being unable to-pay rent. Similarly, children aspired to move to their own homes because of the perceived economic and social benefits, more than the idea of living in a bigger and better house.

The views expressed by children revealed not only what aspects of urban life are important to them but also offered a picture of life in the informal rental sector that reveals something of the dynamics of the rental sector more generally. From their positions as observers on the margins of adult society, the children offered frank descriptions of noisy, unruly spaces characterised by social conflict. These spaces are at odds with the orderly physical spaces imagined by planners, which require only the provision and consolidation of physical shelter to meet human demands for homes. Instead, the children showed that, in order to settle in urban space, a level of social capital is required that is not readily achievable within the informal rental sector. 
This research therefore has implications both for urban planners and for those concerned to promote 'child-friendly cities'. For children, urban space is not simply an abstract space to be filled by planners, perhaps with the participation of children. Children are preoccupied by the social and economic aspects of urban life, which much current housing policy is failing to take seriously.

Some differences emerged between the concerns of children in Maseru and those in Blantyre. Whereas Blantyre children were more likely to associate moving with difficult relationships with landlords and landladies and inability to pay rent, the generally more affluent Maseru children were more concerned about thieves, but they were also more likely to associate migration with a move from rented to owner-occupied accommodation. An exception to this was the out-of-school boys in Maseru who talked at length about neighbourhood problems and relationships with landlords and landladies, perhaps reflecting a level of poverty more typical of Blantyre. It is noteworthy, however, that children in residential care or living on the streets seldom associated migration with renting in their discussions. Furthermore, the prevalence of particular issues in the FGDs, migration pictures, and storyboards seldom related in any apparent way to the gender or age of the group or individual. Overall, there were marked similarities between the concerns expressed by children from the two cities, as well as between girls and boys and between children of different ages.

It must be acknowledged that the research reported here represents only a partial account of children's experiences of life in rented accommodation in Maseru and Blantyre. It cannot be assumed that all children associate renting with migration, and many children may view life in rented accommodation in more positive terms. Nonetheless, for some children, the informal private rental sector represents insecurity and instability, a situation that should be recognised by those advocating private rental as a solution to African housing shortages.

Acknowledgements. This research was funded by the UK Department for International Development (DFID). DFID supports policies, programmes, and projects to promote international development. DFID provided funds for this study as part of that objective, but the views and opinions expressed are those of the authors alone. We gratefully acknowledge also the institutional support of the Institute of Southern African Studies, National University of Lesotho, and the Department of Geography, Chancellor College, University of Malawi, and thank Motsilisi Motsieloa, Lloyd Chitera, and Lumbani Pete for their work as research assistants on the project.

\section{References}

Aitken S C, 2001 Geographies of Young People (Routledge, London)

Ambrose D, 1993 Maseru: An Illustrated History (Morija Museum and Archives, Morija)

Andreasen J, 1996, "Urban tenants and community involvement" Habitat International 20359 - 365

Ansell N, 2002, “ "Of course we must be equal, but ...: imagining gendered futures in two rural southern African secondary schools" Geoforum 33179 - 194

Bartlett S, Hart R, Satterthwaite D, de la Barra X, Missair A, 1999 Cities for Children: Children's Rights, Poverty and Urban Management (Earthscan, London)

Beazley H, 2000, "Street boys in Yogyakarta: social and spatial exclusion in the public spaces of the city", in A Companion to the City Eds G Bridge, S Watson (Blackwell, Oxford) pp $472-488$

Boyden J, Ennew, J (Eds), 1997 Children in Focus: A Manual for Participatory Research with Children Radda Barnen (Swedish Save the Children) Torsg 4, 107 88, Stockholm

Briggs J, Mwamfupe D, 2000, "Peri-urban development in an era of structural adjustment in Africa: the city of Dar es Salaam, Tanzania" Urban Studies 37 797-809

Chawla L, 2001, "Putting young old ideas into action: the relevance of Growing Up in Cities to Local Agenda 21" Local Environment $613-25$

Chawla L, 2002a, "'Insight, creativity and thoughts on the environment': integrating children and youth into human settlement development" Environment and Urbanization 1411 - 21

Chawla L (Ed.), 2002b Growing Up in an Urbanising World (Earthscan, London)

Chawla L, 2002c, "Cities for human development", in Growing Up in an Urbanising World

Ed. L Chawla (Earthscan, London) pp 15-34 
Chawla L, 2002d, "Toward better cities for children and youth", in Growing Up in an Urbanising World Ed. L Chawla (Earthscan, London) pp 219-242

Crankshaw O, Gilbert A, Morris A, 2000, "Backyard Soweto" International Journal of Urban and Regional Research $24841-857$

Englund H, 2002, "The village in the city, the city in the village: migrants in Lilongwe" Journal of Southern African Studies 28137 - 154

Fraser M, 1973 Children in Conflict (Secker and Warburg, London)

Gay J, Hall D, 2000, "Poverty and livelihoods in Lesotho, 2000: more than a mapping exercise", Sechaba Consultants, PO Box 0813, Maseru West, Maseru 0105, Lesotho)

Gay J, Gill D, Hall D, 1995, "Lesotho's long journey_hard choices at the crossroads: a comprehensive overview of Lesotho's historical, social, economic and political development with a view to the future", Sechaba Consultants, PO Box 0813, Maseru West, Maseru 0105, Lesotho

Gill D (Ed.), 1994, “The situation of children and women in Lesotho", Sechaba Consultants, for the Ministry of Planning, Economics and Manpower Development, financed by UNICEF, Private Bag A171, Maseru 100, Lesotho

Grant M, 1996, "Vulnerability and privilege: transitions in the supply pattern of rental shelter in a mid-sized Zimbabwean city" Geoforum 27 247-260

Hart R, 1992 Children's Participation: From Tokenism to Citizenship (UNICEF, Florence)

Holloway S L, Valentine G, 2000, "Children's geographies and the new social studies of childhood", in Children's Geographies: Playing, Living, Learning Eds S L Holloway, G Valentine (Routledge, London) pp $1-26$

Huchzermeyer M, 2001, "Housing for the poor? Negotiated housing policy in South Africa" Habitat International $25303-331$

James A, Jenks C, Prout A, 1998 Theorising Childhood (Teachers College Press, New York)

Jones S, 1993 Assaulting Childhood: Children's Experiences of Migrancy and Hostel Life in South Africa (Witwatersrand University Press, Johannesburg)

Katz C, 1994, "Textures of global changes: eroding ecologies of childhood in New York and Sudan" Childhood $2103-110$

Kishindo E C, 2003, "Women and housing insecurity in Malawi: a study of two low-cost housing projects in Zomba District in Malawi", in Gender and Urban Housing in Southern Africa:

Emerging Issues Eds A Larsson, M Mapetla, A Schlyter (Institute of Southern African Studies, Rome) pp 74-99

Lynch K (Ed.), 1977 Growing Up in Cities (MIT Press, Cambridge, MA)

Magwaza A S, 1992 "Influence of involuntary migration on children's perception of control" Psychological Reports $70707-710$

Malone K, 2001, "Children, youth and sustainable cities" Local Environment 6 5-12

Matthews H, 2003, "Coming of age for children's geographies" Children's Geographies 1 3-5

Matthews H, Limb M, Taylor M, 1999, "Reclaiming the street: the discourse of curfew" Environment and Planning $A 31$ 1713-1730

Matthews H, Limb M, Percy-Smith B, 2000a, "Changing worlds: the microgeographies of young teenagers" Tijdschrift voor Economische en Sociale Geografie 89193 - 202

Matthews H, Taylor M, Percy-Smith B, Limb M, 2000b, "The unacceptable flaneur: the shopping mall as a teenage hangout" Childhood $7279-294$

Morange M, 2002, "Backyard shacks: the relative success of this housing option in Port Elizabeth" Urban Forum 13 - 25

Munthali A C, Ali S, 2000, "Adaptive strategies and coping mechanisms: the effect of HIV/AIDS on the informal social security system in Malawi", Government of Malawi, National Economic Council, Lilongwe

Muzvidziwa V N, 2003, "Housing and survival strategies of Basotho urban women tenants", in Gender and Urban Housing in Southern Africa: Emerging Issues Eds A Larsson, M Mapetla, A Schlyter (Institute of Southern African Studies, Rome) pp 149-168

Norwood H C, 1972, "Ndirande: a squatter colony in Malawi" Town Planning Review 43135 - 150

NSO, 2000, "1998 Malawi Population and Housing Census: Report of Final Census Results", National Statistical Office, Zomba

Ogu V I, Ogbuozobe J E, 2001, "Housing policy in Nigeria: towards enablement of private housing development" Habitat International $25473-492$

Oldfield S, 2000, "The centrality of community capacity in state low-income housing provision in Cape Town, South Africa” International Journal of Urban and Regional Research 24 858-872 
Punch S, 2000, "Children's strategies for creating playspaces: negotiating independence in rural Bolivia”, in Children's Geographies: Playing, Living, Learning Eds S L Holloway, G Valentine (Routledge, London) pp 48-62

Reynolds P, 1989 Childhood in Crossroads: Cognition and Society in South Africa (David Philip, Cape Town)

Robson E, 2000, "Invisible carers: young people in Zimbabwe's home-based healthcare" Area 32 $59-70$

Robson E, Ansell N, 2000, "Young carers in southern Africa: exploring stories from Zimbabwean secondary school students", in Children's Geographies: Playing, Living, Learning Eds S L Holloway, G Valentine (Routledge, London) pp 174- 193

Sandhu R S, Aldrich B C, 1998, "Third World housing: the future is now" Habitat International $22209-213$

Satterthwaite D, Hart R, Levy C, Mitlin D, Ross D, Smit J, Stephens C, 1996 The Environment for Children: Understanding and Acting on the Environmental Hazards that Threaten Children and Their Parents (Earthscan, London)

SC/GPA, 2002, "Regulatory frameworks governing access to legal low-income housing in Maseru", Sechaba Consultants/Geoffrey Payne and Associates, PO Box 0813, Maseru West, Maseru 0105, Lesotho

Stephens S, 1994, "Children and environment: local worlds and global connections" Childhood $\mathbf{2}$ $1-21$

Stewart D W, Shamdasani P N, 1990 Focus Groups: Theory and Practice (Sage, Newbury Park, CA)

Swart-Kruger J, 2002, "Children in a South African squatter camp gain and lose a voice", in Growing Up in an Urbanising World Ed. L Chawla (Earthscan, London) pp 111 - 134

Swart-Kruger J, Chawla L, 2002, “'We know something someone doesn’t know': children speak out on local conditions in Johannesburg" Environment and Urbanization 14 85-96

Tranter P, Pawson E, 2001, "Children's access to local environments: a case-study of Christchurch, New Zealand" Local Environment $627-48$

UNDP, 2002, Human Development Report: Deepening Democracy in a Fragmented World United Nations Development Programme (Oxford University Press, New York)

UNHCS/Habitat, 1996, "Children's rights and habitat: working towards child-friendly cities" United Nations Center for Human Settlements/Habitat, New York

UNICEF, 2003 The State of the World's Children (United Nations Children's Fund, New York)

van Blerk L, Ansell N, forthcoming, "Children's experiences of migration: moving in the wake of AIDS in Southern Africa"

Ward C, 1990 The Child in the City (Bedford Square Press, London)

Watson V, McCarthy M, 1998, "Rental housing policy and the role of the household rental sector: evidence from South Africa" Habitat International 22 49-56

Wilkinson P, 1998, "Housing policy in South Africa" Habitat International 22 215-229

Young L, 2003, "The 'place' of street children in Kampala, Uganda: marginalisation, resistance, and acceptance in the urban environment" Environment and Planning D: Society and Space $21607-627$

Young L, Barrett H, 2001, "Adapting visual methods: action research with Kampala street children" Area $33141-152$ 